\title{
Corsican Language
}

National Cancer Institute

\section{Source}

National Cancer Institute. Corsican Language. NCI Thesaurus. Code C153888.

A Romance language within the Italo-Dalmatian subfamily spoken mainly in Corsica and northern Sardinia. 